\title{
Morphology and distribution of the freshwater mussel Diplodon granosus, a rare and poorly understood species
}

\author{
Igor Christo MIYAHIRA ${ }^{1,2, *}$ (D), Maria Cristina Dreher MANSUR ${ }^{2,3}$, Daniel Mansur PIMPÃO4, \\ Sheyla Regina Marques COUCEIRO5 , Sonia Barbosa dos SANTOS ${ }^{2,6}$

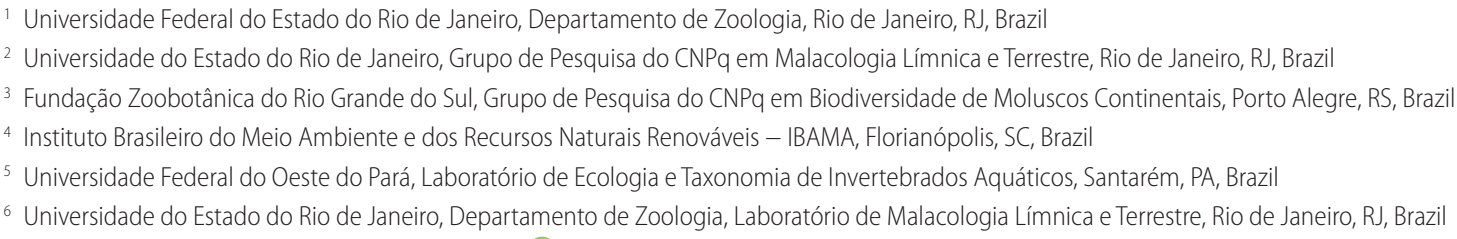

\section{ABSTRACT}

Diplodon granosus was one of the first freshwater mussels to be described for South America. However, the status of the species was confusing for a long time, receiving different taxonomic treatments. In this paper, we redescribe the shell, with new data on the soft parts and information on the distribution and conservation of D. granosus, a rarely recorded species. The shell is thin, not inflated; the macrosculpture is composed only by granules that cover the whole shell, not forming bars; the microsculpture comprises short spikes. In the soft parts we highlight the few, weak and irregularly distributed lamellar connections of the outer demibranch and some features of the stomach, such as the distally enlarged minor typhlosole. There are records of D. granosus over a large area of South America, from Guiana to Argentina. However, most of these records are related to other species and the distribution of D. granosus is restricted to the north of South America in the basins of the Amazonas and Orinoco rivers, and coastal rivers in between. Despite this wide distribution, the species occurs in specific habitats, mainly streams (igarapés), resulting in an extremely fragmented occurrence. Thus, any disturbance to these habitats can threat this freshwater mussel.

KEYWORDS: Unionida, Hyriidae, Rhipididontini, taxonomy, conservation

\section{Morfologia e distribuição do bivalve de água doce Diplodon granosus, uma espécie rara e pouco conhecida}

\section{RESUMO}

Diplodon granosus foi um dos primeiros bivalves de água doce descritos para a América do Sul. Contudo, o status dessa espécie foi confuso por um longo tempo, recebendo diferentes tratamentos taxonômicos. Neste estudo, apresentamos a redescrição da concha, assim como novos dados da anatomia das partes moles, e informaçóes acerca da distribuiçáo e conservaçáo desta espécie raramente avistada. A concha é fina, não-inflada; a macroescultura é composta somente por grânulos que cobrem toda a concha, e não formam raios; a microescultura é composta por espinhos curtos. Nas partes moles, destacamos as poucas, fracas e irregularmente distribuídas conexóes interlamelares da demibrânquia externa, assim como algumas características do estômago, como a tiflossole menor distalmente aumentada. Existem registros de D. granosus em uma grande área da América do Sul, da Guiana até a Argentina. Contudo, muitas destas ocorrências sáo relacionadas com outras espécies, estando D. granosus restrita às bacias dos rios Amazonas e Orinoco, e a rios costeiros entre essas duas bacias. Apesar desta aparente ampla distribuiçẫo, a espécie ocorre em habitats específicos, principalmente riachos (igarapés), resultando em uma distribuição fragmentada. Assim, qualquer modificação nestes ambientes pode ameaçar esta espécie.

PALAVRAS-CHAVE: Unionida, Hyriidae, Rhipididontini, taxonomia, conservação

\section{INTRODUCTION}

Diplodon granosus (Bruguière, 1792) is one of the first species of freshwater mussels (Unionida: Hyriidae) described for South America. Initially it has been included as a valid species in descriptive global lists and catalogues (e.g., Lamarck 1819; Hanley 1843). Later, Simpson (1900; 1914) placed Diplodon multistriatus (Lea, 1831), Diplodon pfeifferi (Dunker, 1848) and Diplodon psammactinus (Philippi, 1848) in synonymy with $D$. granosus. Haas $(1931 ; 1969)$ considered three subspecies for D. granosus: D. granosus granosus, D. granosus ellipticus Spix in Wagner, 1827 and D. granosus multistriatus. He also concluded that the distribution of $D$. granosus granosus is so extensive that 
some synonyms should be subspecies. Martínez-Escarbassiere and Royero (1995) presented a brief description of the shell and some details of the glochidium of $D$. granosus. Recent revisions, mostly based on shell features, considered $D$. granosus as valid, with several species in synonymy (Simone 2006; Graf and Cummings 2007; Pereira et al. 2014; Miyahira et al. 2017), yet its soft parts were still practically unknown. Recently, Diplodon ellipticus and D. multistriatus were redescribed (Miyahira et al. $2013 ; 2019)$ and the differences of these species compared to D. granosus were pointed out. However, detailed information on Diplodon granosus is still missing.

The confusion in taxonomy affected the understanding of the distribution of $D$. granosus. Firstly restricted to the rivers of French Guiana (Bruguière 1792), the distribution range of the species was extended as successive taxonomic treatments placed the species in synonymy. Different authors registered the species from Guayana [sic] to São Paulo, in southeastern Brazil (Haas 1969), in Suriname (Leentvaar 1993), in the Amazonas and Paraná rivers, and coastal rivers in Brazil from the states of Bahia to São Paulo (Simone 2006), in the Amazonas and Orinoco basins and in the São Francisco and Paraná basins (Graf and Cummings 2007), in the Orinoco Basin in Venezuela (Martínez-Escarbassiere et al. 2004; Martínez-Escarbassiere and Royero 1995), and in Argentina (Rumi et al. 2008). Overall, the current distribution of $D$. granosus extends from Venezuela, Suriname and French Guiana to Argentina, excluding only the Magdalena River basin and Pacific drainages.

The aim of this study was to redescribe Diplodon granosus, providing data for a consistent identification of the species, including new information on morphology and taxonomy. Based on our newly acquired knowledge, we revised and updated the distribution range of the species and its conservation status.

\section{MATERIAL AND METHODS}

Specimens from the following museums were studied: Instituto Nacional de Pesquisas da Amazônia (INPA, Manaus - Brazil), Universidade do Estado do Rio do Janeiro (UERJ, Rio de Janeiro - Brazil), Zoologische Staatssammlung München (ZSM, Munich - Germany), Senckenberg Forschungsinstitut und Naturmuseum (SMF, Frankfurt - Germany), Florida Museum of Natural History (FLMNH, Florida - USA), Illinois Natural History Survey (INHS, Illinois - USA) and National Museum of Natural History (USNM, Washington D.C. - USA). The latter three institutions had the material checked through the MUSSELp site (http://mussel-project. uwsp.edu/). Pictures of the type specimen were requested to the MNHN (Muséum National d'Histoire Naturelle, Paris France). Other museums in Brazil, Uruguay, Argentina and Germany were visited, however specimens from this species were not found. It was common to find specimens identified as $D$. granosus in museum collections, but most of these were misidentifications of other species. All specimens studied were only shells, except for the material from UERJ, which was composed of five whole specimens that were used for the description of soft parts. Based on the examined material, we updated the species' distribution map.

The morphology (shell and soft parts) was described according to Mansur and Anflor (1981), Ricci et al. (1988), Mansur and Pereira (2006), and Miyahira et al. (2019). The microsculpture of the shell was described following the proposals for Anodontites Bruguière, 1792 by Callil and Mansur (2005), with modifications (see Miyahira et al. 2019). The nomenclature for the form, type and structures of the glochidium shell follows Pimpão et al. (2012).

\section{RESULTS}

\section{Diplodon granosus (Bruguière, 1792)}

(Figures 1-4)

Unio granosa Bruguière, 1792: 103; Lamarck 1819: 79; Lea 1829: 424; Lea 1834: 91.

Margarita (Unio) granosa (Bruguière, 1792): Lea 1836: 17. Iridea granosa (Bruguière, 1792): Swainson 1840: 379; Nuttall 1990: 267.

Unio granosus Bruguière, 1792: Hanley 1843: 182.

Margaron (Unio) granosus (Bruguière, 1792): Lea 1852: 23; Lea 1870: 34.

Diplodon (Diplodon) granosus (Bruguière, 1792): Simpson 1900: 878, in part; Simpson 1914: 1250, in part; Ortmann 1921: 485, in part; Morretes 1949: 17, in part; Rumi et al. 2008: 84, in part; Martínez-Escabassiere et al. 2004; Pereira et al. 2012: 91; Pereira et al. 2014: 24.

Diplodon (Diplodon) granosus granosus (Bruguière, 1792): Haas 1931: 31, in part; Bonetto 1964: 324, in part; Haas 1969: 525, in part.

Diplodon granosus (Bruguière, 1792): Parodiz 1968: 6, 18; Simone 2006: 259, in part; Graf and Cummings 2007: 312; MartínezEscarbassiere and Royero, 1995: 80; Lasso et al. 2009: 72.

Material examined. VENEZUELA, Bolivar: tributary of Erebata River, 24/iii/1981, R. Franz et al. (FLMNH 29407); Guanare River, El Miamo, 11/i/1994, K.S. Cummings et al. (INHS 14954); Yuruari River, El Manteco, 9/i/1994, K.S. Cummings et al. (INHS 14950); Território Federal Amazonas: Negro River, Siapa River, Raudal Timoshoteri, 21/i/1989, R. Martinez and R. Royero (INHS 16984); GUYANA, Cuyuni-Mazaruni: small tributary of Cuyuni River, Kamaria, 22/vii/1925, P.E. Morrison (USNM 428118); FRENCH GUIANA, Cayenne: a short distance from the sea, M. Leblond (MNHN 1710 - 33). BRAZIL, Amazonas: Igarapé Irapirapi, Pohoro Indian Post, 29/09/1994, Py-Daniel and Barbosa (INPA 1035); Pará: Belterra, igarapé in National Forest of Tapajós, 2012, S. Couceiro (UERJ 10480); Caraipé River, Tucuruí, 09/1982, C.S. Motta (INPA 511); Paru de 

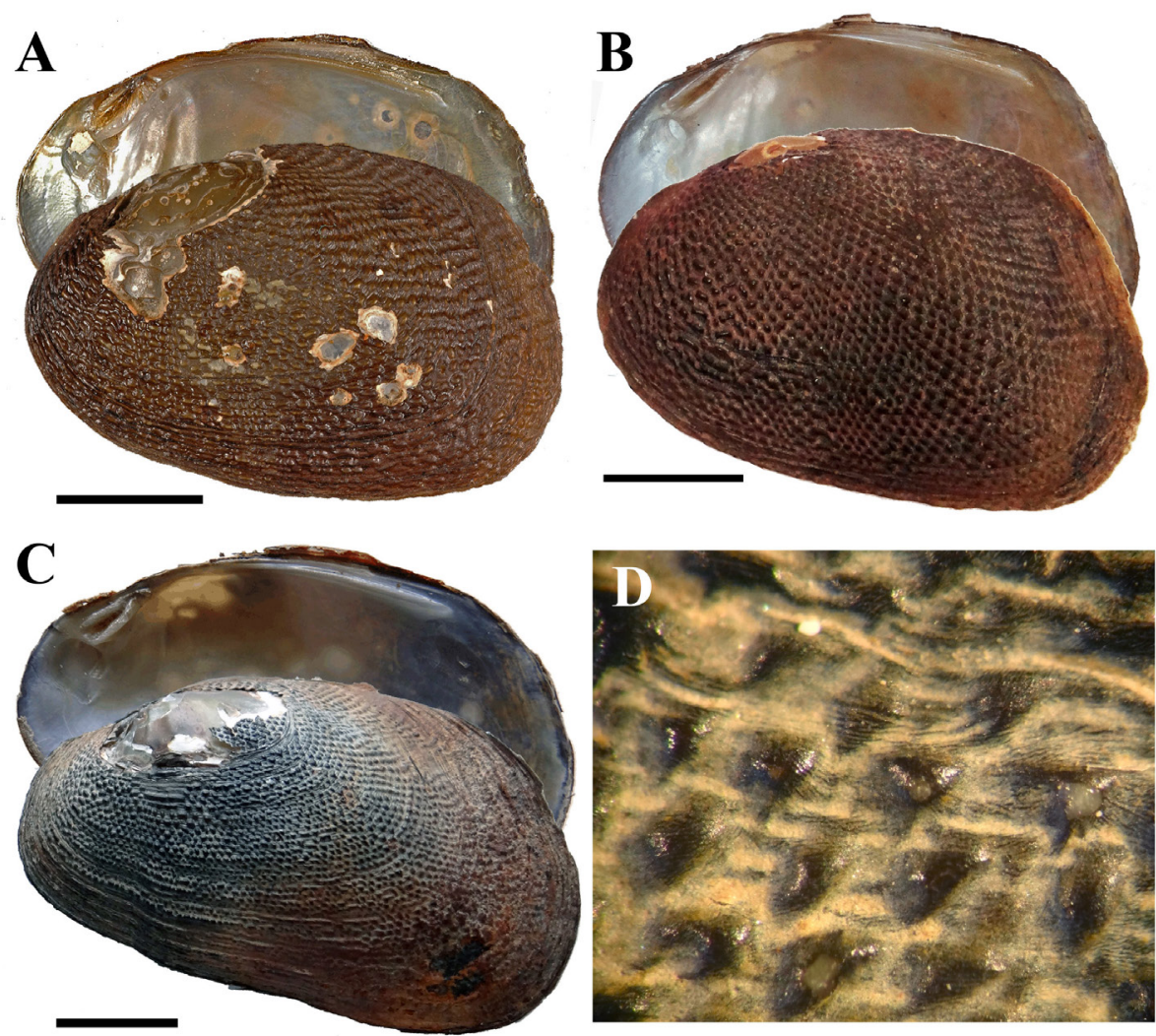

Figure 1. Shell of Diplodon granosus (Bruguière, 1792): A - MNHN 1710 (Holotype), Cayenne, French Guiana; B - ZSM A354, Pará, Brazil; C - UERJ 10480, Belterra, Pará, Brazil; and $D$ - Detail of the granules of the macrosculpture and the mesoscopic wrinkles over them (magnification $=63 \mathrm{x}$ ). Scale bars $=1 \mathrm{~cm}$. This figure is in color in the electronic version.

Oeste River, 07/1967, R. Geisler (SMF 2381); Igarapé Akahe, Tumucumaque Mountain Range, 15/03/1962, Fittkau (ZSM 935); Roraima: Tepequém Mountain Range, 25/07/2006, D. Coscarelli (INPA 1196); Maracá Ecological Station, Igarapé Paubaru, Santa Rosa, “Tiporen” waterfall, 03/2008, V.T. Carvalho (INPA 1424).

Type locality. River of Cayenne (French Guiana) at a short distance from the sea (Bruguière 1792). The name of the river is not mentioned. The city of Cayenne is bordered by Cayenne River and Mahury River.

Etymology. Granosus, meaning "with grains", reference to the granules of the macrosculpture that covers almost the whole shell.

Type material. The collection of Bruguière is housed at MNHN (Dance 1966) and the holotype is catalogued under the number 1710 and was collected by Jean Baptiste LeBlond (Bruguière 1792). Measurements of the holotype (length $\mathrm{x}$ height x width): 37.3 mm x 24.34 mm x 13.40 mm. Bruguière (1792) offered the measurements, in the same order, as 18 lines $(=37.4$ $\mathrm{mm}) \times 1$ inch 5 lines $(=40.6 \mathrm{~mm}) \times 6$ lines $(=13.5 \mathrm{~mm})$. The length and width measurements are very close to those taken by us, but the height is completely divergent. The measurements by Bruguière (1792) result in a square-like shell, contradicting his own drawings and Figure 1. According to Marshall (1930), the way in which Bruguière measured could explain this difference: the length would be equal to the "traditional" measurement of height, and the width to the "traditional" length. Even considering this discrepancy, one of the measurements still does not make sense. It is possible that he measured the valves in another unusual way or a typographical error may have occurred.

Diagnosis. Shell of small size, thin, not inflated, outline ovoid; macrosculpture composed by granules that cover almost the whole shell, organized in rows that do not form bars.

Redescription of the shell. Shell of small size $(<5 \mathrm{~cm})$; not inflated (Table 1). Shell outline ovoid, length greater than height, anterior region lower than posterior, anterior margin rounded, posterior margin truncated, dorsal and ventral margins curved, both in half-ellipse (Figure 1). Valve fragile, thin, translucent when opposed to the light. Posterior ridge low and rounded. Beaks low, without exceeding the hinge line, beaks located up to 2/5 of the shell length, usually eroded. Short and low ligament,

Table 1. Basic measurements (in mm) of Diplodon granosus (Bruguière, 1792) based on the holotype (MNHN 1710) and on UERJ $10480(n=5)$.

\begin{tabular}{lccc}
\hline & Length & Height & Width \\
\hline Mean \pm SD & $38.1 \pm 3.5$ & $24.6 \pm 2.0$ & $13.3 \pm 1.3$ \\
Maximum & 43.1 & 27.6 & 14.8 \\
Minimum & 33.8 & 22.2 & 11.3 \\
\hline
\end{tabular}


spreading from beak to the middle of lateral teeth length. Shell macrosculpture composed on granules (each $-500 \mu \mathrm{m}$ ) that cover almost completely the shell surface, aligned in rows that are convergent on the disc and divergent on the anterior and posterior regions. Periostracum light to dark brown, dull. Concentric folds of periostracum visible only at shell margins, where granules are absent. Periostracum with narrow and relatively small wrinkles, a mesoscopic sculpture, occurring over the whole shell, including over the granules of the macrosculpture (Figure 1d, 2). The wrinkles are of different lengths, width of approximately 10-20 $\mu \mathrm{m}$, looking like elongated narrow folds that can be straight or diagonal to each other (Figure 2). The wrinkles give an overall dull and rugose aspect to the shell surface (Figure 1d). Microsculpture composed of very short spikes $(-1 \mu \mathrm{m})$ that apparently occur over the whole shell, including the wrinkles (Figure 2c-d); microfibers and microdepressions were not observed.

Nacre greyish white, iridescent, generally with brown rounded spots, shell edge without internal thickening (Figure 1). Right valve with two cardinal teeth, lower tooth longer, taller and thicker with radial furrows, upper tooth shorter, about half the thickness of the lower cardinal tooth, small protuberance posterior to cardinal teeth acting like an accessory tooth, one lateral tooth. Left valve with one thin and lamellar cardinal tooth, lateral teeth double, both tooth of same thickness.
Anterior adductor muscle scar deep and rounded, posterior adductor muscle scar shallow and elongated. Umbonal cavity shallow, three radial grooves departing from the umbonal cavity in ventral direction. Two to four dorsal muscle scars.

General morphology of soft parts. Inhalant and exhalant openings not projecting; exhalant opening smooth, corresponding to $65.9 \%$ of the inhalant opening (Figure 3); inhalant opening with conical simple tentacles of approximately same width, aligned in a single line in the lower region of inhalant opening, in a double line without overlapping in the upper region; internal tentacles longer than the external. Demibranchs of homogenous height, or the outer surpassing the internal at the posterior section; external demibranch usually triangular, with few and weak interlamellar junctions, without clear organization pattern; internal demibranch trapezoid. Marsupium in a central position of internal demibranch, occupying $61 \%$ of demibranch length in the observed specimen; marsupium filling starts by the anterior portion. Labial palp triangular, small extension of the dorsal margin fused $(-35 \%$ of the length). Anterior and posterior adductor muscles of similar size, posterior larger, both nearly elliptical in shape. Posterior pedal retractor and pedal protractor fused to respective adductor muscle; anterior foot retractor slight detached from the adductor. Two to four dorsal muscles, usually the last one is rectangular and elongated.

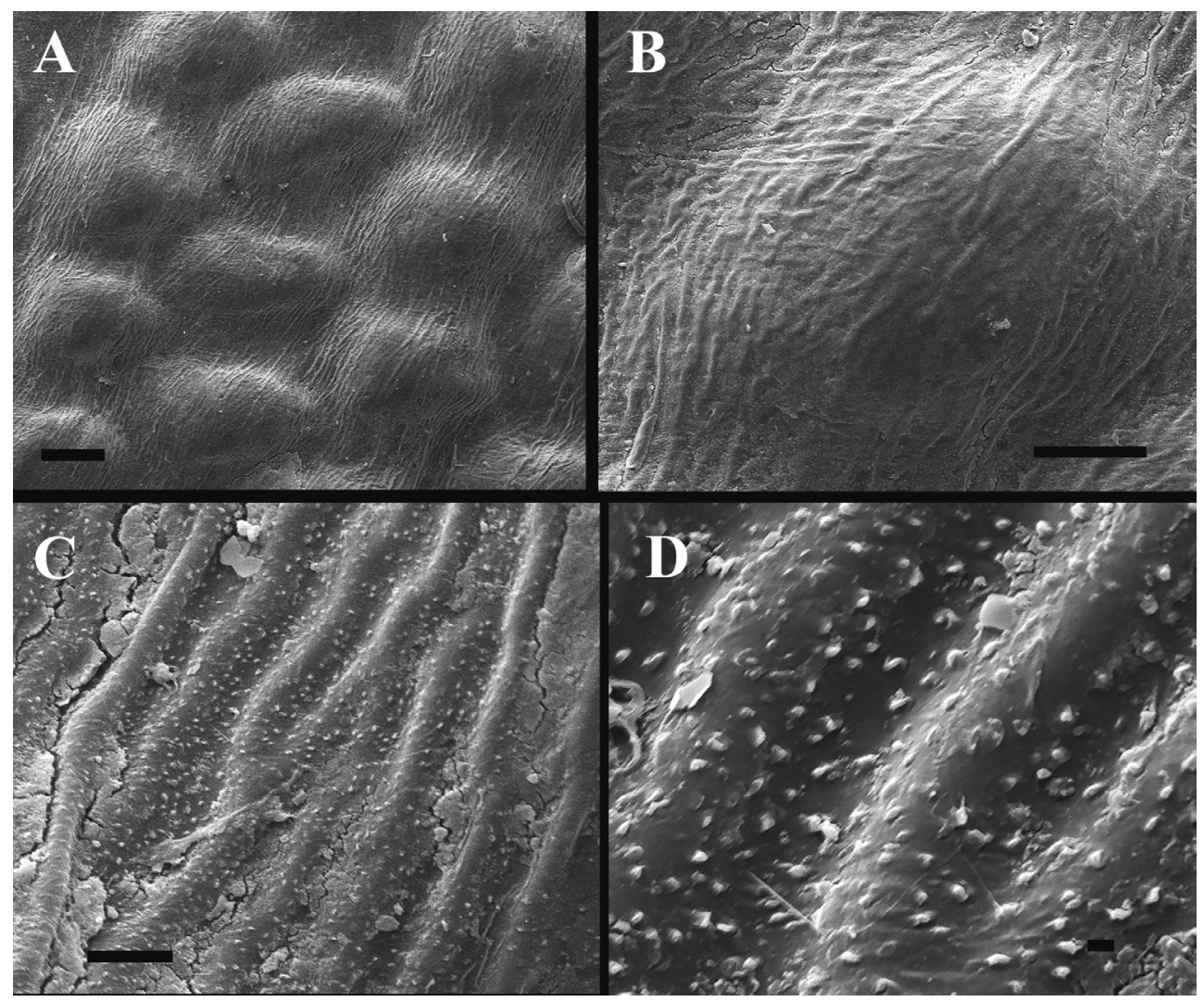

Figure 2. Meso and microsculpture of Diplodon granosus (Bruguière, 1792): A - Overview of the granules of the shell; B - Detail of one granule covered by mesoscopic wrinkles; $C$ - Wrinkles covered by spikes of the microsculpture; and D - Detail of the wrinkles with several spikes. Scale bars, $A=200 \mu \mathrm{m}, B=100 \mu \mathrm{m}, C=20 \mu \mathrm{m}, D=2 \mu \mathrm{m}$. 
A

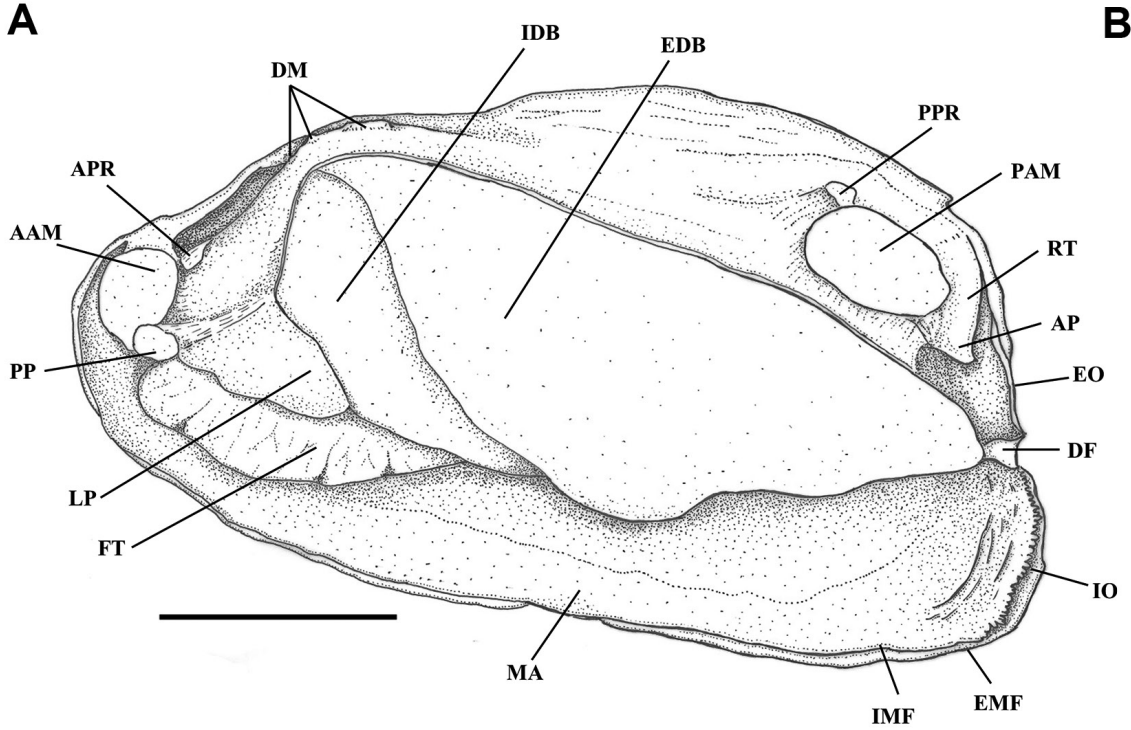

C

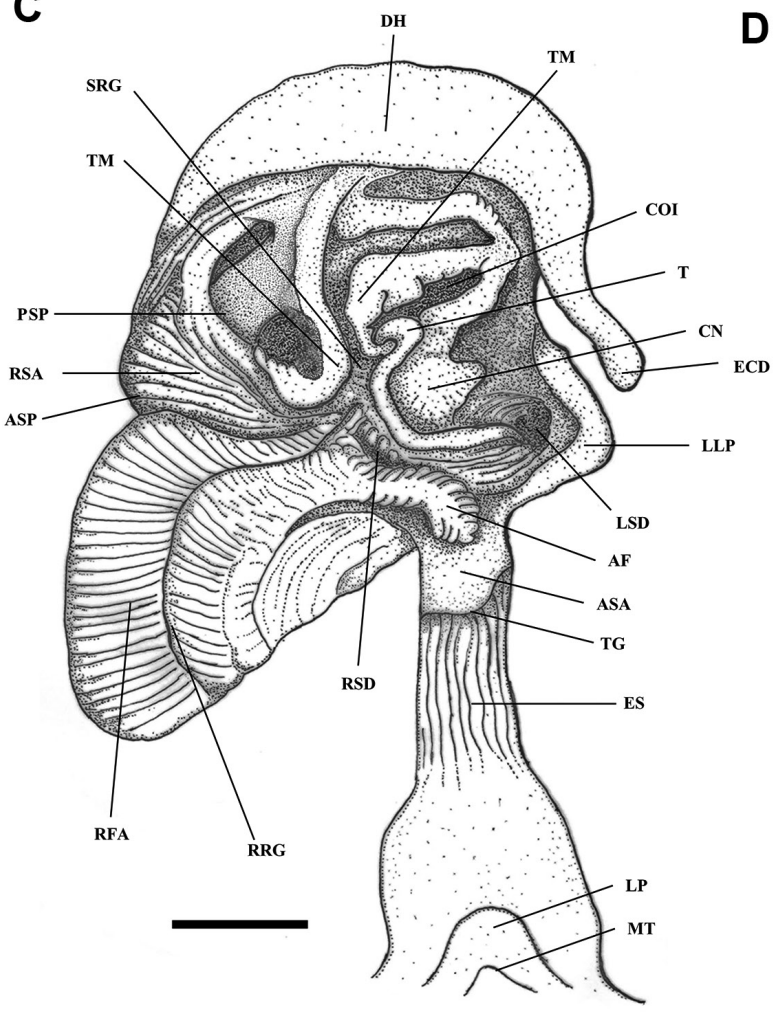

B
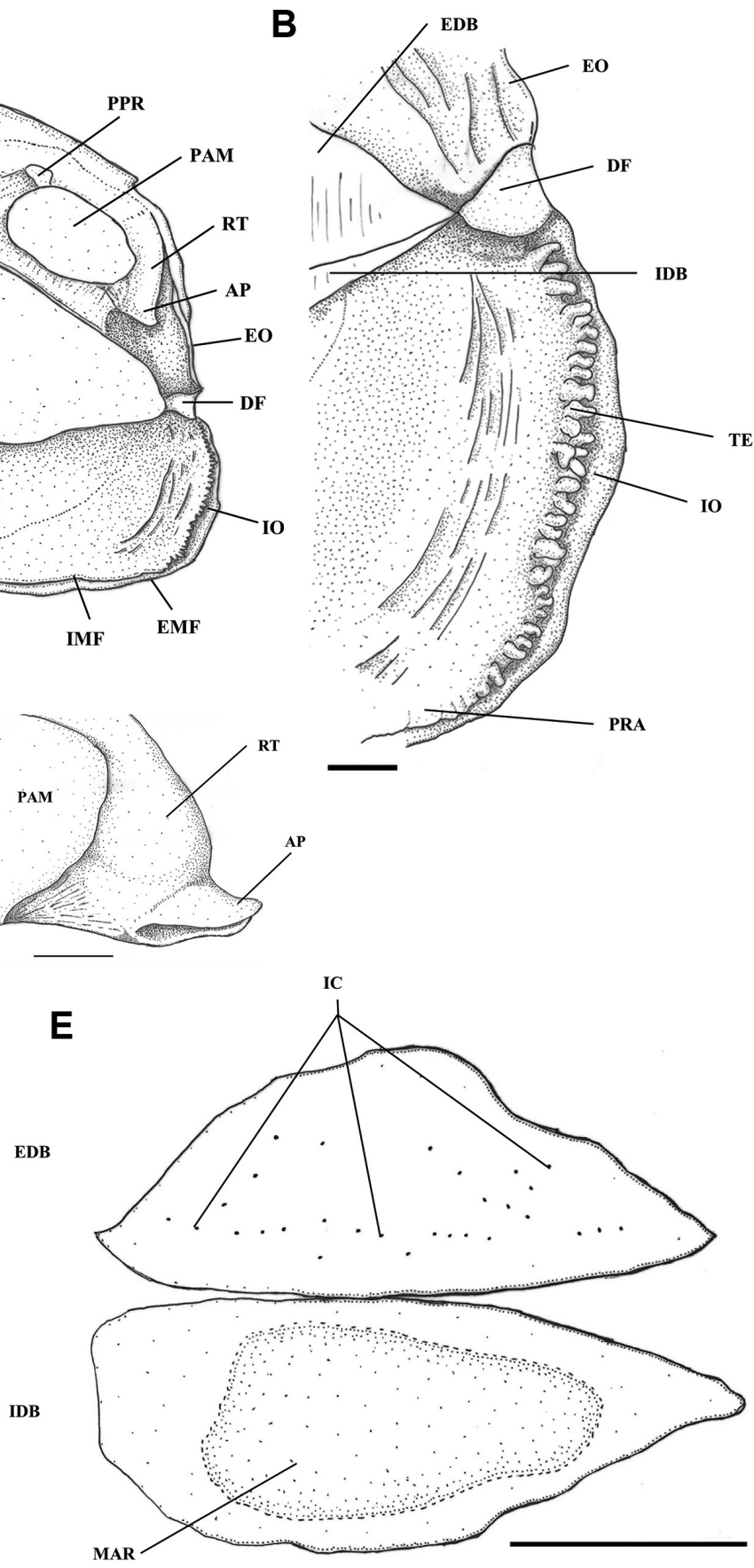

Figure 3. Anatomy of Diplodon granosus (Bruguière, 1792): A - General overview of the soft parts; $B$ - Detail of inhalant opening; $C$ - First section of the digestive system (stomach); D - Anal papilla; $E$ - Outlines of demibranch and marsupium. Scale bars: $A, E=1 \mathrm{~cm} ; B, C, D=1 \mathrm{~mm}$. Abbreviations: $A A M=$ anterior adductor muscle, $A F=$ anterior fold, $\mathrm{AP}=$ anal papilla, $\mathrm{APR}=$ anterior pedal protractor muscle, $\mathrm{ASA}=$ anterior selection area ( $\mathrm{SA7}$ ), $\mathrm{ASP}=$ anterior selection pouch, $\mathrm{CN}=\mathrm{conical}$ protuberance, $\mathrm{COI}=$ common opening of intestine and stylet sac, $\mathrm{DF}=$ diaphragm, $\mathrm{DH}=$ dorsal hood, $\mathrm{DM}=$ dorsal muscles, $\mathrm{EDB}=$ external demibranch, $\mathrm{EMF}=$ external mantle fold, EO = exhalant opening, ES = esophagus, $\mathrm{FT}=$ foot, IC = interlamellar connections, IDB = internal demibranch, IMF = internal mantle fold, IO = inhalant opening, $L L P=$ left side projection, $L P=$ labial palp, $L P=$ lip, $L S D=$ opening of left side diverticula, $M A=$ mantle, $M A R=$ marsupium, $M M F=$ middle mantle fold, $M T=$ mouth, PAM = posterior adductor muscle, $\mathrm{PP}=$ pedal protractor muscle, $\mathrm{PRA}=$ pseudofeces rejection area, $\mathrm{PPR}=$ posterior pedal protractor muscle, $\mathrm{PSP}=$ posterior selection pouch, $\mathrm{RFA}=$ stomach roof selection area (SA8), RRG = stomach roof rejection groove, $\mathrm{RSA}=$ right side selection area (SA3), $\mathrm{RSD}=$ opening of right side diverticula, $\mathrm{RT}=$ rectum, $\mathrm{SRG}=$ stomach floor rejection groove, $\mathrm{T}=$ typhlosole, $\mathrm{TE}=$ tentacles, $\mathrm{TG}=$ transversal groove, $\mathrm{TM}=$ minor typhlosole. 
Digestive system. Mouth with a V-shapped indent; buccal cavity bell shaped. Esophagus narrow; transversal groove well-marked. Stomach pear-shaped in dorsal view; anterior selection area with shallow folds; anterior fold voluminous and projected, with transversal lobes of regular size, gradually diminishing towards the stomach roof; right side selection area wide and with two pouches; stomach-roof selection area with grooves of similar size and divided by the rejection groove, which continues through the stomach floor, increasing in width towards the common opening of stomach and sytlet sac, that is surrounded by a thick annulus. Major typhlosole narrower than minor typhlosole, surrounding a slightly projected cone. Minor typhlosole ends "J" shaped and a little larger distally, near the pouches of the right side, with gently and short distal folds. Dorsal hood not deep, with the narrower distal part relatively short reaching the level of the left duct openings. Rectum with a sphincter that regulates the release of feces, before ending in a single anal papilla.

Glochidia. Among the specimens with soft parts examined by us (UERJ 10480), which were collected in Belterra, Pará state (Brazil) in October 2012, there was one gravid female with encapsulated embryos. No mature glochidia were found.

Appointments on glochidium structure were based on Martínez-Escarbassiere and Royero (1995), who presented the glochidium of Diplodon granosus using specimens from Venezuela collected in February 1989. They described and illustrated the glochidium as of parasite type, relatively big, presenting the following measurements: length $=286.03 \mu \mathrm{m}$; height $=27.42 \mu \mathrm{m}$; dorsal line length $=188.1 \mu \mathrm{m}$ and angle of obliquity $=2.88^{\circ}$. The value for height is probably a mistake, as it indicates an extremely low glochidium, in disagreement with their own images (Martínez-Escarbassiere and Royero 1995). From the figure in the latter publication, we estimated the height of the specimen to be $265.4 \mu \mathrm{m}$. Thus, it is probable that a typing error may have occurred, and the correct original value was $274.2 \mu \mathrm{m}$, very close to our measurement.

From Figure 2b, 3 and 4 in Martínez-Escarbassiere and Royero (1995), we were able to describe the additional details on glochidium morphology. Glochidium outline similar to equilateral triangle; ventral edge in a sub-central position, less externally pronounced than in Diplodon ellipticus (Miyahira et al. 2019), posterior and anterior regions of similar size; shell with undulations and pores; border of the glochidium slightly internally projected; glochidial hooks "S" shaped, apparently shorter than in D. ellipticus (Miyahira et al. 2019), glochidial hook with three terminal cusps, central cusp longer; protuberance at the base of glochidial hook low and rounded.

Distribution. This species occurs in coastal rivers of French Guiana; Essequibo River and Orinoco River basins (Guyana and Venezuela); Amazonas River basin (Venezuela and Brazil) and lower Tocantins River basin (Brazil) (Figure 4). According to the records available to us, the species does not occur homogeneously throughout these basins, as it frequently occurs in streams or igarapés, as they are known in the Brazilian Amazon. Igarapés

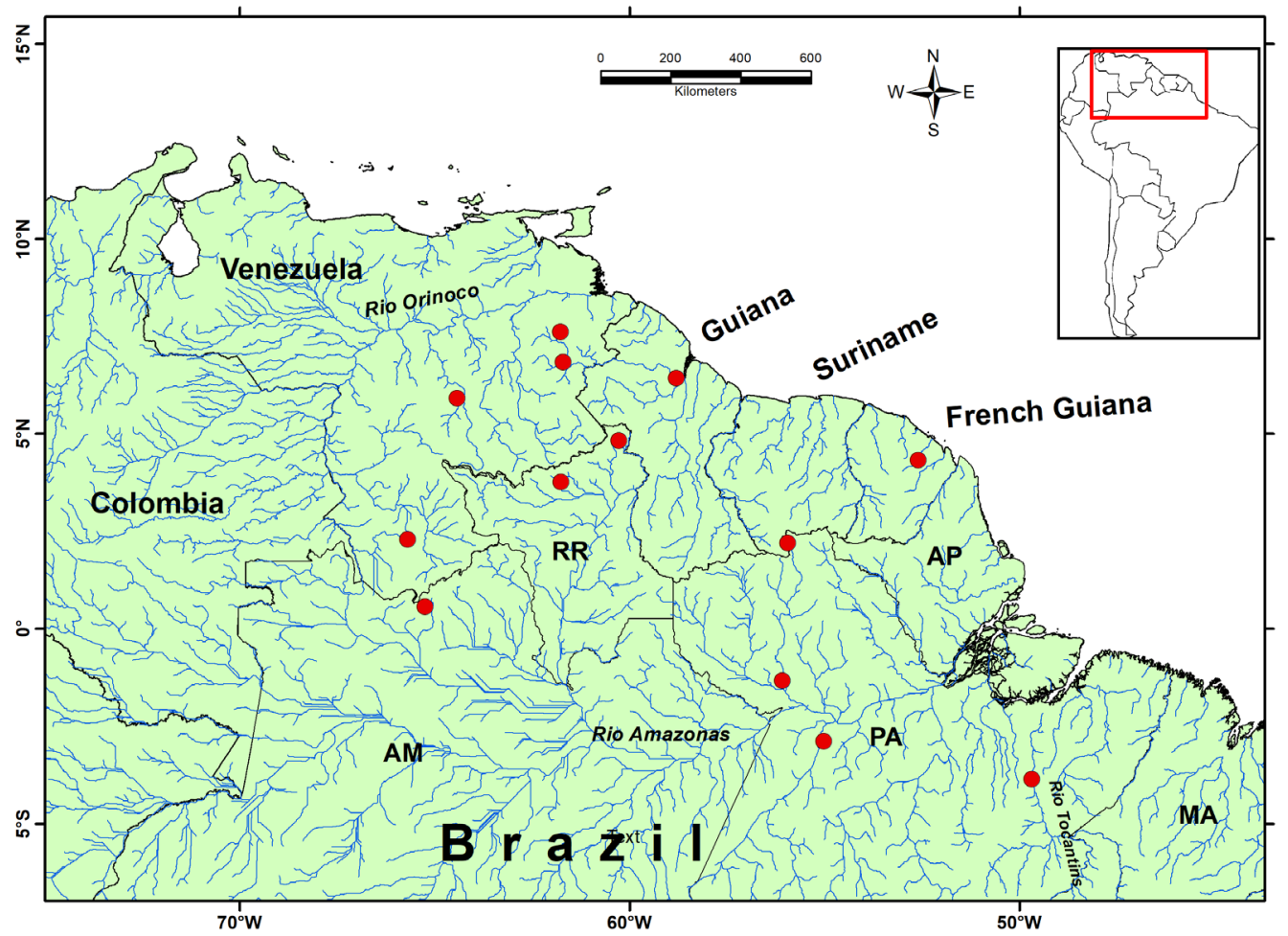

Figure 4. Distribution of Diplodon granosus (Bruguière, 1792) in northern South America, based on the material examined in the present study. This figure is in color in the electronic version. 
are small and shallow courses of slightly acid water, usually with few suspended sediments. The specimens collected in Floresta Nacional do Tapajós, in Belterra, Pará (UERJ 10480), were found in a small igarapé where the forest on one margin had been transformed into pastures. At the collection site, the stream was $6.9 \mathrm{~m}$ wide, $0.66 \mathrm{~m}$ deep, with slightly acid water ( $\mathrm{pH} 6.4$ ), low conductivity $\left(24.65 \mathrm{mS} \mathrm{cm} \mathrm{cm}^{-1}\right)$, moderate suspended solid concentration $\left(12.23 \mathrm{mg} \mathrm{l}^{-1}\right)$, water current of $0.42 \mathrm{~m} \mathrm{~s}^{-1}$, high water temperature $\left(27.4^{\circ} \mathrm{C}\right)$ and dissolved oxygen of $6.75 \mathrm{mg}$ $\mathrm{l}^{-1}$ (SRMC, unpublished data). The species was also recorded in whitewater rivers with good transparency $(-40 \mathrm{~cm})$ and $\mathrm{pH} 6.5$ (Martínez-Escarbassiere and Royero 1995), and on sandy bottom (Martínez-Escarbassiere et al. 2004). Even in streams the species seems not to be common. The five specimens of the UERJ 10480 record were found in only one igarapé out of ten surveyed.

Remarks. Lamarck (1819) was the first to comment on this species after the original description and claimed that the specimen was in his cabinet (at MNHN). Lea (1834) said that the only specimen of D. granosus seen by him in Europe was the specimen in Jardin des Plantes of Paris, where the MNHN is located). It is quite possible that Lamarck (1819) and Lea (1829; 1834) referred to the same specimen, the holotype. Lea $(1829,1834)$ considered this species very pretty and distinct from all other species of Rhipidodontini. Hanley (1843) presented a brief description, emphasizing the presence of granules crowding the shell. These three latter authors applied a restrictive view of D. granosus, as did Parodiz (1968) and Nuttall (1990). The former concluded that D. granosus was an exclusive and little know species from French Guiana, and that records 1500 miles $(-2400 \mathrm{~km})$ south from the type locality must be incorrect. However, other authors still identified non-amazonian records as D. granosus over the years. Simpson (1914) included some species described for Brazil in the synonymy of $D$. granosus, such as $D$. multistriatus, $D$. psammactinus and D. pfeifferi. Haas $(1931,1969)$ proposed three subspecies for D. granosus, and illustrated the species with others related to $D$. multistriatus, such as D. granuliferus and $D$. coriaceus, both described for the state of Rio de Janeiro (Miyahira et al. 2017; 2019). Simone (2006) made a similar arrangement and illustrated Diplodon granosus with a specimen of Diplodon multistriatus, adding two species that are synonym with Diplodon multistratus (D. granuliferus and $D$. psammactinus) in the synonymy of $D$. granosus. These authors considered a wide variation on the macrosculpture of D. granosus, from independent granules to smooth bars. Simone (2006), Graf and Cummings (2007) and Pereira et al. (2014) considered the species as valid, without any subspecies.

\section{DISCUSSION}

The authors that considered other species in the synonymy of D. granosus (e.g. Simpson 1914; Ortmann 1921; Haas 1969; Simone 2006) possibly deduced that the specimen presented by Bruguière (1792) represented the extreme of a range of morphological variation. The inclusion of other species, such as D. multistriatus, D. granuliferus, D. expansus, $D$. coriaceus and D. pfeifferi, in the synonymy of D. granosus was probably due to the similar shell outline and the presence of grains in the macrosculpture of these species. However these similarities are only superficial; the umbonal sculpture of $D$. multistriatus and other related species (e.g. D. granuliferus, $D$. expansus, D. coriaceus and D. pfeifferi) is composed of imbricated bars in a net pattern, wihch is thickened when the bars cross each other (Miyahira et al. 2013; 2019). The sculpture of $D$. multistriatus never extends over the whole shell, as is common to all known specimens of D. granosus. The sculpture of $D$. granosus is composed only by granules, with no connection among them (i.e. without the presence of bars). These granules are larger than the grains found at the end of the bars at the umbonal macrosculpture of other species, and also cover almost the entire shell, except the borders. The sculptural pattern observed in D. granosus was not recorded in any other species of Rhipidodontini, but appears in another hyriid, Triplodon chodo Mansur \& Pimpáo, 2008 (Mansur and Pimpão 2008). In Rhipidodontini, the macrosculpture of D. granosus can be considered exclusive (i.e. diagnostic) and an easy feature to identify this species. Diplodon granosus has a small and thin shell, usually with eroded umbones. These shell features are probably related to the habitat of the species, with slightly acidic water and low nutrient level, typical of igarapé environments, which limit growth and shell thickness.

The microsculpture of $D$. multistriatus, which is sometimes confused with D. granosus, is composed of elongated spikes, microfibers and microdepressions (Miyahira et al.2019), while on the shell surface of $D$. granosus there are only short spikes, and microfibers and microdepressions were not observed. The spikes of $D$. ellipticus are very similar to those of D. granosus, however, they occur along the microfibers. The microsculpture was not known to many species of Rhipidodontini, but it is proving to be useful in species delimitation. Other differential characteristic of the D. granosus sculpture is the presence of mesoscopic wrinkles on the shell surface. This intermediatesize sculpture is not observed in the Rhipidodontini species redescribed by Miyahira et al. (2019), whereas the microdepressions and microfibers of the microsculpture of those species were not found in D. granosus.

The description of soft parts also added information for a better definition of this species. The external demibranch is triangular with few, weak and not organized lamellar connections. The general external demibranch outline of $D$. multistriatus and D. ellipticus can be similar, however, these two species present more lamellar connections (Miyahira et al. 2019). The anterior fold of the stomach found in D. granosus is similar to that of D. ellipticus, but with more lobes, and is more robust than the fold of $D$. multistriatus (Miyahira et al. 2019).

The general outline of the glochidium of $D$. granosus is almost an equilateral triangle, while in other species of 
Rhipidodontini the glochidia usually look like a scalene triangle (Martínez-Escarbassiere and Royero 1995; Mansur 1999; Pimpão et al. 2012; Miyahira et al. 2019). Unfortunately, it was not possible to obtain specimens with mature glochidia to improve our observations. However, the detailed examination of the images in Martínez-Escarbassiere and Royero (1995) allowed us to improve the description of the glochidia of $D$. granosus. Despite the relatively large size of the glochidia of this mussel (Martínez-Escarbassiere and Royero 1995), the hook is apparently small, and can also be diagnostic for this species, though more specimens need to be analyzed.

After our extensive museum survey and analysis of specimens of D. granosus for its redecription, it became clear that the specimen used by Bruguière (1792) in the original description does not represents an extreme of shell variation, but is the typical form of the species. All the other species previously related to D. granosus, like D. multistriatus, have features (shell, soft parts or glochidia) that allow us to differentiate them. Thus, it is not possible to consider $D$. multistriatus and D. ellipticus as subspecies of D. granosus, as proposed by Haas (1969). Diplodon psammactinus, D. coriaceus and D. granuliferus, included by Haas (1969) and Simone (2006) in synonymy of D. granosus, should be removed, as these three species are related to D. multistriatus (Miyahira et al. 2019). Similarly, D. nuloticus (sic = niloticus Sowerby, 1868 ) and D. famelicus (Gould, 1850), which were also placed in synonymy with D. granosus (Simone 2006) are not related to this species. The first was described for the Nile River and possibly does not even belong to Diplodon; the second is described from Oregon (USA), but its type locality could be an error (information on the type lot label, USNM 5929). Diplodon famelicus does not present granules on the macrosculpture covering the whole shell, as does D. granosus. Thus, other nominal species that were previously included in the synonymy list of $D$. granosus should be removed.

Diplodon granosus presents parasite glochidia, a S-shaped glochidial hook, a protuberance at the base of the hook, microsculpture of the shell with short spikes and few and weak lamellar connections on the outter demibranchia. Miyahira et al. (2019) presented a tentative and updated definition of both genera included in Rhipidodontini, Diplodon and Rhipidodonta. The redescription of D. granosus fits into the proposal for Diplodon by these authors, strengthening the definition. Among the characteristics listed by Miyahira et al. (2019) for the genus Diplodon, only the microfibers were not observed in D. granosus.

The specimens of Diplodon recorded under the name "D. granosus" in the literature include a wide range, from the extreme north of South America to Argentina (e.g. Bruguière 1792; Haas 1969; Simone 2006; Rumi et al. 2008). However, our reevaluation of the species restricted its distribution to the north of South America (Figure 4). Only the specimens from the north of South America fit into the description here presented. The records south of the Amazonas River basin are considered as in need of further revision and are probably related to other species. Thus, the species occurs only in the basins of the Amazonas, lower Tocantins and Orinoco rivers, and in coastal rivers of northern South America. Diplodon granosus seems to prefer small water bodies, specially small streams or igarapés, but even in this environment it seems not to be a common species. For example, the description of the soft parts was based on only five specimens. The material on the species in other museum collections was usually composed of small lots, which probably owes to sparse populations at the collection points. Surveys of freshwater mussels in the Amazonas River basin did not record specimens of D. granosus in the Uraricoera and Branco rivers (Mansur and Valer 1992), Madeira and Aripuanã rivers (Pimpão 2007), Aripuanã River (Pimpão and Mansur 2009), and the confluence of the Negro and Solimóes rivers (Pimpão et al. 2008). The species also was not not recorded in areas of the Pantanal region bordering the Amazon region (Serrano et al. 1998; Colle and Callil 2012). All these surveys recorded other Diplodon species. Therefore, D. granosus seems to have a wide distribution, but not continuous and extremely fragmented.

The igarapé environment is not continuous in the Amazon biome, which can partially justify the apparent patchy distribution of the species. The Amazon biome is less modified than other Brazilian biomes, however, the lower Tocantins River is one of the most impacted areas in the region, with many large hydropower reservoirs, and extensive areas of cropland and pasture. In Belterra (Pará, Brazil), where some specimens used in this study were collected, the forest has also partially been converted into pasture and the collection site is frequented by local people for waterside leisure. Igarapés frequently suffer the effects of anthropogenic impacts (Callisto et al. 1998; Couceiro et al. 2010; Matos et al. 2011; Falcão et al. 2012; Martins et al. 2017) from deforestation, illegal mining and forest fires. There are plans to install several hydroelectric powerplants in the Amazonas River basin (Winemiller et al. 2016), which could aggravate the impacts to low order streams by altering their hydrologic dynamics and environmental characteristics. These impacts, associated to an extremely fragmented distribution, can represent a threat to this species. In addition, invasive species have also spread in the Amazon basin over the last years (Beasley et al. 2003; Pimpão and Mansur 2008; Silva and Silva-Forsberg 2015). In the most recent edition of the Brazilian Red Book of Threatened Species (ICMBio 2018), D. granosus was classified as of Least Concern (the species categorized as LC were not published, but authors ICM and SBS participated in the evaluation process). However, the new information presented here should be sufficient for a reevaluation of the conservation status of the species.

The glochidium is of parasite type but the host fish(es) of D. granosus are still unknown. This information is extremely 
important for a better understanding of the life cycle and restricted distribution of this mussel, and to adequately support conservation strategies.

\section{CONCLUSIONS}

Our data suggest that Diplodon granosus is a valid species, clearly differentiated from other Rhipidodontini species. It is distributed exclusively in northern South America and is likely in need of conservation efforts and further studies to improve the knowledge on its distribution, life cycle and ecology.

\section{ACKNOWLEDGMENTS}

Our gratitude goes to Conselho Nacional de Desenvolvimento Científico e Tecnológico - CNPq (PROTAX \# 562291/2010-5, Universal \# 434964/2018-2) for financial support to SBS and a scholarship to ICM; to the collection curators at Instituto Nacional de Pesquisas da Amazônia - INPA (Célio Magalhães), Muséum National d'Histoire Naturelle - MNHN (Philippe Maestrati), Senckenberg Forschungsinstitut und Naturmuseum - SMF (Ronald Janssen), Universidade do Estado do Rio de Janeiro - UERJ (Maria Regiana Salgado) and Zoologische Staatssammlung München - ZSM (Michael Schröld and Enrico Schwabe) for pictures and/or support during museum surveys; to M.F. Oliveira (UERJ) for support with SEM pictures; and to anonymous reviewers and editor who helped improve the manuscript with comments and suggestions.

\section{REFERENCES}

Beasley, C.R,; Tagliaro, C.H.; Figueiredo, W.B. 2003. The occurence of the Asian Clam Corbicula fluminea in the lower Amazon basin. Acta Amazonica, 33: 317-323

Bonetto, A.A. 1964. Las especies del Género Diplodon (Moll. Unionacea) en los ríos de la pendiente Atlántica del sur del Brasil. Physis, 24: 323-328.

Bruguière, J.G. 1792. Sur une nouvelle espéce de Mulette. Journal d'Histoire Naturelle, 1: 103-109.

Callil, C.T.; Mansur, M.C.D. 2005. Ultrastructural analysis of the shells of Anodontites trapesialis (Lamarck) e Anodontites elongatus (Swaison) (Mollusca, Bivalvia, Etherioidea) from the Mato Grosso Pantanal Region, Brazil. Revista Brasileira de Zoologia, 22: 724-734.

Callisto, M.; Esteves, F.A.; Gonçaves, J.F.; Leal, J.J.F. 1998. Impacts of bauxite tailings on the distribution of benthic macrofauna in a small river ('igarapé) in Central Amazonia, Brazil. Journal of the Kansas Entomological Society, 71: 447-455.

Colle, A.C.; Callil, C.T. 2012. Environmental influences on the composition and structure of the freshwater mussels in shallow lakes in the Cuiabá River floodplain. Brazilian Journal of Biology, 72: 249-256.

Couceiro, R. M.; Hamada, N.; Forsberg, B.R.; Padovesi-Fonseca, C. 2011. Trophic structure of macroinvertebrates in Amazonian streams impacted by anthropogenic siltation. Austral Ecology, 36: 628-637.
Falcão, M.T.; Buás, A.I.C.; Pinheiro M.N.M.; Oliveira, S.K.S. 2012. Impactos ambientais no igarapé Wai Grande em Boa Vista Roraima decorrentes da influência do Aterro Sanitário. Revista Geonorte, 3: 199-207.

Graf, D.L.; Cummings, K.S. 2007. Review of the systematic and global diversity of freshwater mussel species (Bivalvia: Unionoida). Journal of Molluscan Studies, 73: 291-314.

Haas, F. 1931. Versuch einer kritischen Sichtung der sudamerikanischen Najaden, hauptsachlich an Hand der Sammlung des Senckenberg-Museums II. Senckenbergiana, 13: $30-52$.

Haas, F. 1969. Superfamilia Unionacea. In: Mertens, R.; Hennig, W.; Wermuth, H. (Ed.). Das Tierreich, v. 88. Walter de Gruyter e Co., Berlin, p.1-663.

Hanley, S.C.T. 1843. An illustrated e descriptive catalogue of recent bivalve shells. Williand \& Norgate, London, 392p.

ICMBio. 2018. Livro vermelho da fauna brasileira ameaçada de extinção. Instituto Chico Mendes de Conservação da Biodiversidade, Brasília, 492p.

Lamarck, J.B.P. 1819. Historie Naturelle des Animaux sans Vertèbres. A. Belin, Paris, $575 \mathrm{p}$.

Lasso, C.A.; Martínez-Escarbassiere, R.; Capelo, J.C.; MoralesBetancourt, M.A.; Sánchez-Maya, A. 2009. Lista de los moluscos (Gastropoda-Bivalvia) dulceacuícolas y estuarinos de la cuenca del Orinoco (Venezuela). Biota Colombiana, 10: 63-74.

Lea, I. 1829. Description of a new genus of the family of Naïades, including eight species, four of which are new; also the description of eleven new species of the genus Unio from the rivers of the United States: with observations on some of the characters of the Naïades. Transactions of the American Philosophical Society, 3: 403-457.

Lea, I. 1834. Observations on the genus Unio, together with descriptions of new genera and species in the families naiades, Conchae, Colimacea, Lymnaeana, Melaniana and Peristomiana. James Kay, Jun. and Co., Philadelphia, 233p.

Lea, I. 1836. A Synopsis of the Family Unionidae, 1th ed. Cary, Lea and Blanchard, Philadelphia, 59p.

Lea, I. 1852. A Synopsis of the Family Unionidae, 3th ed.. Blanchard and Lea, Philadelphia, 88p.

Lea I. 1870. A Synopsis of the Family Unionidae, 4th ed. Henry C. Lea, Philadelphia, 184p.

Leentvaar, P. 1993. The man-made Brokopondo Lake. In: Ouboter, P.E. (ed.) The Freshwater Ecosystems of Suriname. SpringerScience, Dordrecht, p.227-238.

Mansur, M.C.D. 1999. Gloquídio de Diplodon martensi (Ihering) (Mollusca, Bivalvia, Hyriidae) e seu ciclo parasitário. Revista Brasileira de Zoologia, 16: 185-194.

Mansur, M.C.D.; Anflor, L.M. 1981. Diferenças morfológicas entre Diplodon charruanus (Orbigny, 1835) e D. pilsbry Marshall, 1928 (Bivalvia: Hyriidae). Iheringia Série Zoologia, 60: 101-106.

Mansur, M.C.D.; Pereira, D. 2006. Bivalves límnicos da bacia do rio dos Sinos, Rio Grande do Sul, Brasil (Bivalvia, Unionoida, Veneroida e Mytiloida). Revista Brasileira de Zoologia, 23: 1123-1147.

Mansur, M.C.D.; Valer, R.M. 1992. Moluscos bivalves do rio Uraricoera e rio Branco, Roraima, Brasil. Amazoniana, 12: 85-100. 
Mansur, M.C.D.; Pimpão, D.M. 2008. Triplodon chodo, uma nova espécie de bivalve de água doce da bacia Amazônica (Mollusca: Bivalvia: Unionoida: Hyriidae). Revista Brasileira de Zoologia, 25: 111-115.

Marshall, W.B. 1930. Former and present terms used in describing fresh-water mussels. The Nautilus, 44: 41-42.

Martínez-Escarbassiere, R.; Royero, R. 1995. Contribución al conocimiento de Diplodon (Diplodon) granosus granosus Brugeri (Bivalvia: Hyriidae) y Doryssa hohenackeri kappleri Vernhout (Gastropoda: Melaniidae) en el alto Rio Siapa (Departamento Negro), estado Amazonas, Venezuela. Acta Biologica Venezuelica, 16: 79-84.

Martínez-Escarbassiere, R.; Cabrera, A.; Lasso, C.A. 2004. Moluscos bivalvos (Unionacea y Mutelacea) de la cuenca del rio Orinoco, Venezuela. Memoria de la Fundación La Salle de Ciencias Naturales, 159-160: 283-303.

Martins, R.T.; Couceiro, S.R.M.; Melo, A.S.; Moreira, M.P.; Hamada, N. 2017. Effects of urbanization on stream benthic invertebrate communities in Central Amazon. Ecological Indicators, 73: 480 - 491.

Matos, F.C.; Targa, M.S.; Batista, G.T.; Dias, N.W. 2011. Análise temporal de expansão urbana no entorno do Igarapé Tucunduba, Belém, PA, Brasil. Revista Biociências, 17: 7-16.

Miyahira, I.C.; Mansur, M.C.D.; Santos S.B. 2013. Revision of the type specimens of Diplodon ellipticus and Diplodon expansus (Bivalvia, Unionoida, Hyriidae). Spixiana, 36: 173-182.

Miyahira, I.C.; Santos, S.B.; Mansur, M.C.D. 2017. Freshwater mussels from South America: state of the art of Unionida, specially Rhipidodontini. Biota Neotropica 17: e201703441.

Miyahira, I.C.; Mansur, M.C.D.; Santos S.B. 2019. Redescription of Diplodon ellipticus Spix in Wagner, 1827; Diplodon multistriatus (Lea, 1831), and Rhipidodonta garbei (Ihering, 1910) (Bivalvia: Hyriidae) from coastal rivers of eastern and northeastern Brazil. Archiv für Molluskenkunde, 148: 9-34.

Morretes, F.L. 1949. Ensaio do catálogo dos moluscos do Brasil. Arquivos do Museu Paranaense, 7: 5-216.

Nuttall, C.P. 1990. A review of the Tertiary non-marine molluscan faunas of Pebasian and other inland basins of north-western South America. Bulletin of the British Museum (Natural History), Geology series, 45: 165-371.

Rumi, A.; Gregoric, D.E.G; Núńez V, Darrigran GA. 2008. Malacologia Latinoamericana - Moluscos de agua dulce de Argentina. Revista de Biologia Tropical, 56: 77-111.

Ortmann, A.E. 1921. South American naiades; a contribution to the knowledge of the fresh-water mussels of South America. Memoirs of the Carnegie Museum, 8: 451-670.

Parodiz, J.J. 1968. Annotated catalogue of the genus Diplodon (Unionacea - Hyriidae). Sterkiana, 30: 1-22.

Parodiz, J.J. 1973. The species complex of Diplodon delodontus (Lamarck) (Unionacea - Hyriidae). Malacologia, 14: 247-270.

Pereira, D.; Mansur, M.C.D.; Pimpão, D.M. 2012. Identificação e diferenciação dos bivalves límnicos invasores dos demais bivalves natives do Brasil. In: Mansur, M.C.D.; Santos, C.P.; Pereira, D.; Paz, I.C.P.; Zurita, M.L.L.; Rodriguez, M.T.R.; Nehrke, M.V.;
Bergonci, P.E.A. (Org). Moluscos Límnicos Invasores no Brasil: Biologia, Prevenção e Controle. Redes Editora, Porto Alegre, p.75-94.

Pereira, D.; Mansur, M.C.D.; Duarte, L.D.S.; Oliveira, A.S.; Pimpão, D.M.; Callil, C.T.; et al. 2014. Bivalve distribution in hydrographic regions in South America: historical overview and conservation. Hydrobiologia, 75: 15-44.

Pimpão, D.M. 2007. Moluscos. In: Rapp Py-Daniel, L.H.; Deus, C.P.; Henriques, A.L.; Pimpão, D.M.; Ribeiro, O.M. (Org.). Biodiversidade do Médio Rio Madeira: Bases Cientificas para Propostas de Conservação. INPA/MMA/MCT, Manaus, p.69-81.

Pimpão D.M.; Martins, D.S. 2008. Ocorrência do moluscos asiático Corbicula fluminea (Müller, 1774) (Bivalvia, Corbiculidae) no baixo rio Negro, Amazônia central. Acta Amazonica, 38: 589-592

Pimpão, D.M.; Mansur, M.C.D. 2009. Chave pictórica para identificação dos bivalves do rio Aripuanã, Amazonas, Brasil (Sphaeriidae, Hyriidae e Mycetopodidae). Biota Neotropica, 9: 377-384.

Pimpão, D.M.; Rocha, M.S.; Fettuccia, D.C. 2008. Freshwater mussels of Cataláo, confluence of Solimóes and Negro rivers, state of Amazonas, Brazil. Check List, 4: 395-400.

Pimpão, D.M.; Mansur, M.C.D.; Bergonci, P.E.A.; Beasley, C. 2012. Comparative morphometry and morphology of glochidial shells of Amazonian Hyriidae (Mollusca: Bivalvia: Hyriidae). American Malacological Bulletin, 30: 73-84.

Ricci, C.N.; Coelho, A.C.S.; Alvarenga, L.C.F. 1988. Diplodon (D.) multistriatus (Lea, 1831): Concha, partes moles e consideraçôes taxonômicas (Mollusca, Bivalvia, Hyriidae). Boletim do Museu Nacional, Zoologia, 325: 1-19.

Serrano, M.A.S.; Tietböhl, R.S.; Mansur, M.C.D. 1998. Sobre a ocorrência de moluscos bivalves no Pantanal de Mato Grosso, Brasil. Biociências, 6: 131-144.

Silva, A.F.; Silva-Forsberg, M.C. 2015. Espécies exóticas invasoras e seus riscos para a Amazônia Legal. Scientia Amazonia, 4: 114-124.

Simone, L.R.L. 2006. Land and Freshwater Molluscs of Brazil. EGBFapesp, São Paulo, 390p.

Simpson, C.T. 1900. Synopsis of the freshwater naiades, or pearly fresh-water mussels. Proceedings of the United States National Museum, 22: 501-1044.

Simpson, C.T. 1914. A Descriptive Catalogue of the Naiades or Pearly Freshwater Mussels. Privately published by Bryant Walker, Detroit, $1540 \mathrm{p}$.

Swainson, W. 1840. A Treatise on Malacology. Longman, Orne, Brown, Green and Longmans, London, p.419.

Winemiller, K.O.; McIntyre, P.B.; Castello, L.; Fluet-Chouinard, E.; Giarrizzo, T.; Nam, S.; et al. 2016. Balancing hydropower and biodiversity in the Amazon, Congo and Mekong. Science, 351: 128-129.

RECEIVED: $17 / 10 / 2019$

ACCEPTED: 26/12/2019

ASSOCIATE EDITOR: Bruno Spacek Godoy 